\author{
Review Article
}

\title{
BHRAMARI PRANAYAMA: A NON-PHARMACOLOGICAL APPROACH AGAINST CURRENT CORONAVIRUS DISEASE 19 PANDEMIC
}

\section{Nisha Garg1*, Srikanta Kumar Panda ${ }^{2}$}

${ }^{*}$ PG. Scholar, ${ }^{2}$ Associate Professor, Department of Kriya Sharir, Ayurvedic and Unani Tibbia College and Hospital, New Delhi, India.

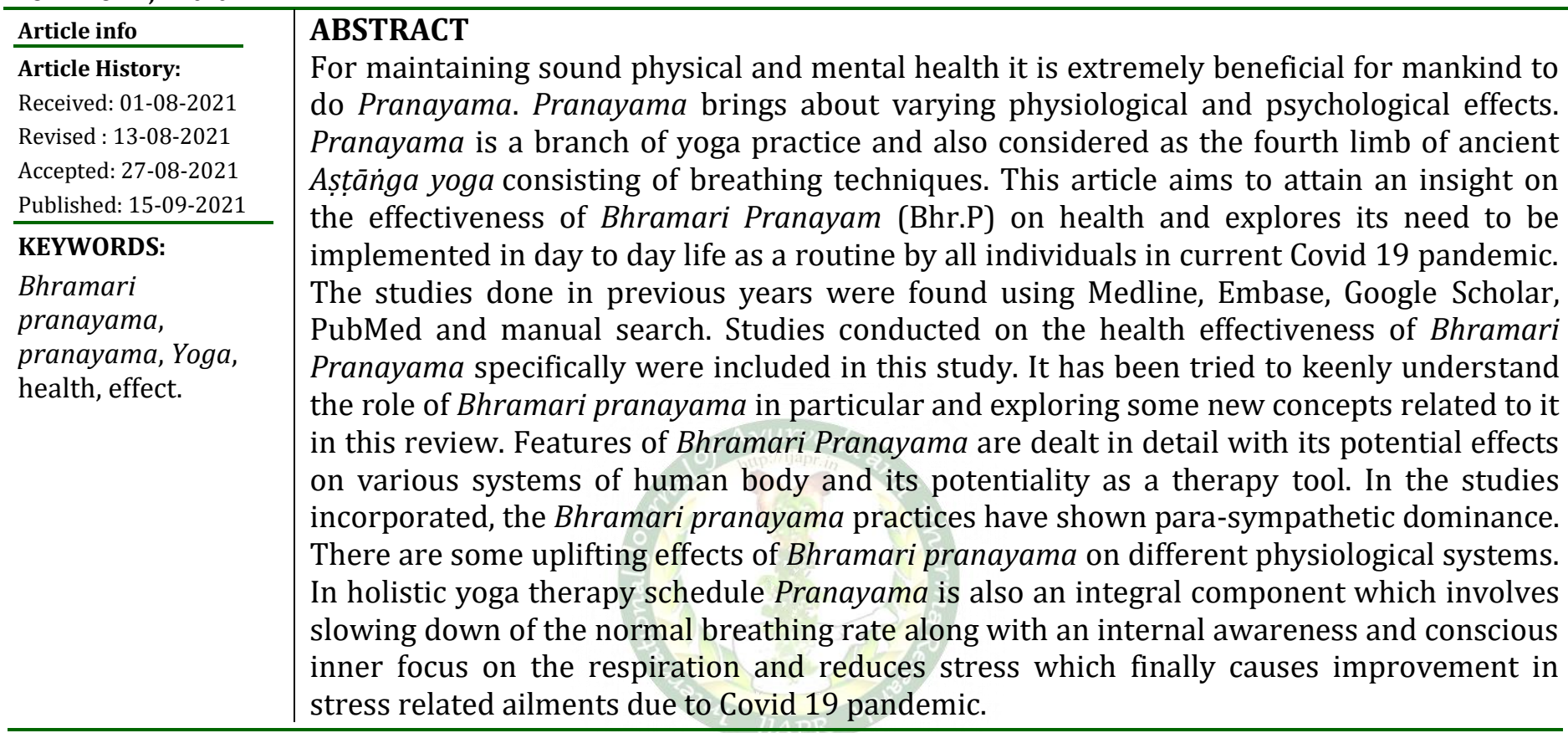

\section{INTRODUCTION}

Prānāyāma is among the most important yogic practices. Yoga includes practice of specific posture (āsana), regulated breathing (Prānāyāma) etc.[1] Maharishi Patanjali, in his Ashtanga yoga, has given more importance to Pranayama than asana for good health. ${ }^{[2]}$ In human beings, the breath is an active connection between the body and mind while the Pranayama is considered as manipulation of once own breathing. [3] Pranayama, by regular practice reduce the dead space and as a result decrease the workload of breathing. Shallow breathing only refreshes the base of the lung, on the other hand lung as a whole get ventilated as a result of Pranayama practice.[4]

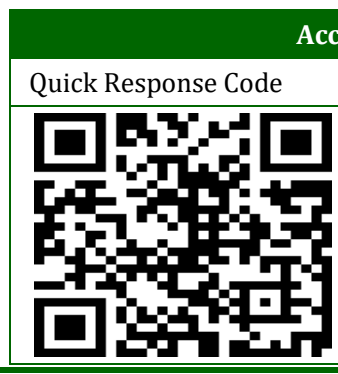

https://doi.org/10.47070/ijapr.v9i8.1970

Published by Mahadev Publications (Regd.) publication licensed under a Creative Commons Attribution-NonCommercialShareAlike 4.0 International (CC BY-NC-SA 4.0)
Prana is the vital or etheric force which is more subtle than air and can be defined as the energy essence that is within everything in the universe. Yama means to 'control'. Pranayama can be defined as a series of techniques which stimulate and increase the vital energy and ultimately bringing about perfect control over the flow of Prana within the body. Pranayama should not be considered as just breathing exercises, aimed at introducing extra oxygen into the lungs, though of course this is a very valuable aspect. Pranayama utilizes breathing to influence the flow of Prana in the Nadis (Pranic channels) of the Pranayama kosha (the body of bio energy) purifying them and also induces physical and mental stability.[5] And thus finally, helps in increasing or normalizing the oxygen concentration in blood. Oxygen is said as Vishnupadamrita[6] by Acharya Sharangadhar i.e. nectar of the atmosphere, which is essential for cellular metabolism or aerobic metabolism. 


\section{Importance of Breathing Style in Life Span}

Man's life span depends much on his mode of respiration. Most of us breathe incorrectly, using only a small part of our lung capacity.[7] A person who breaths in short, quick gasp is likely to have a shorter life than a person who breathes slowly and deeply. The ancient Yogis estimated a person's life span, not in years but by the number of his/her respirations. They considered that everyone is allocated a fixed number of respirations in his life, differing for each person. Life can be prolonged by making each respiration longer. By breathing deeply one is able to get more vitality or Prana from each respiration. Respiration is directly related to the heart. Slow respiration occurs with a slow - beating heart, and a slow beating heart is conducive to long life. ${ }^{[8]}$ As it has been told in lay man's language that "jab tak sans tab taka aas".

The duration of inhalation in the day brings man's mind into relationship with the external environment. The duration of exhalation predominates during sleep and allows man to enter the world of peace and rest.[9]

\section{Bhramari Pranayama}

Bhramara means a huge black colour bumblebee and its name is so, because during exhalation a soft humming sound likes that of a bumble-bee is produced.[10] The Bhramari Pranayam is supposed to be the commencing stage for balancing the mind and also for internalizing the awareness.

Dhyan is 8 times superior to Japa, Tapa (austerity) is 8 times superior to Dhyanan, and music is 8 times superior to tapas. There is nothing greater than music.

The ideal posture for Bhramri Pranayam is comfortable meditation Aasana which can be Padmasana or Siddhasana keeping spinal cord erect and the head straight. Bring the hands upto the ears by raising the arms sideways and bending the elbows. Obstruct the passage of ears by using the index or middle finger. Inhalation followed by slow exhalation has to be done in a controlled manner meanwhile making a deep steady humming sound. The Humming sound should be smooth, even and continuous during the duration of the exhalation. This is one round.

Duration: Five to ten rounds are sufficient in the beginning which can be increased to 10 to 15 minutes.

Time of practice: the best to practice is early morning or midnight. However, it can be practiced anytime, subject to peaceful surrounding.

Contraindications: It should not be performed while lying down and those who are suffering from severe ear infections also should not do.[11]

\section{Need for the Review}

There are a number of benefits of practicing Bhramari pranayama and various studies have been conducted exploring these benefits, still there is a dearth of available documentation on specific Pranayama individually. The Bhr.P is one unique technique having many health benefits but very few scientific evidences available showing its effects. Most of the literatures that are available are having shared effects of Pranayama practices as a whole. We have systematically reviewed the available studies and in this literature review, attempts have been done to explore the existing scientific studies on the Bhr.P. This review could lead in further for recognizing gaps in the existing studies as well as exploring the new floor for scientific advances in this field.

\section{METHODOLOGY}

\section{Search Criteria}

The search was done online in Medline, PubMed, Embase and Google Scholar as well as manual search was also carried out till June 2021 to make the search exhaustive and identified multiple studies done on Bhramari Pranayam. The key words used were pranayama, Bhramari pranayama, benefits, effects, practice of Bhramari. The words having similar meaning of the key words were also used for the search.

\section{Selection of Studies}

Inclusion Criteria: The studies done specifically on Bhramari Pranayam and its benefits over various bodily systems.

Exclusion Criteria: The studies that don't include Bhramari Pranayam practice were excluded.

Relevant literature also collected from available textbooks and newspaper articles.

\section{Data Extraction}

After the in depth search and sorting out studies based on the inclusion criteria, the data extraction was done. Then the final set of manuscript was prepared by the authors and information was thematically extracted. The data extracted include the objective of the study, the methodology employed, salient findings and the conclusions of various researches.

\section{Data Synthesis}

After the data extraction, the data synthesis was done by categorizing the study findings under different relevant headings.

\section{RESULTS}

\section{Why Bhramari Pranayam is more Relevant than other Pranayam and Yoga}

For achieving good breathing pattern, there are various ways and forms of Pranayama that also cures many disorders. "Bhramari" is one such technique that is intensely practiced in yogic exercises. It is considered as one of the kind of traditional yogic breathing practice that not only includes a unique breathing technique but also related with 
simultaneous causing a constant humming sound generation during the phase of expiration making the body feel in the state of relaxation. Its simplicity of slow breathing and that it could be smoothly practiced by everyone without any age or gender related foundation makes it notifiable.[12] In Bhr.P, the practitioner will sit in any posture that is comfortable, inhale and exhale through nostrils slowly and deeply.[13]

Mantra repetition technique seems to be parallel to this when we look into the benefits of this Pranayama. Bhramari impacts the normal breathing rhythm, by prolonging the exhalation and shortening the inhalation period producing significant effect on physiological system.[14]

\section{Effects of Bhramari Pranayam on Human Physiology}

Each and every form of Pranayama has its own beneficial effect based on their technique involving breathing cycle, tidal volume and other factors like the use of mouth, nostrils, constriction of laryngeal muscles and position of the glottis.[15] The humming sound of Bhramari pranayam induces sleep and is good for persons suffering from insomnia. [16]

Bhramari practice also plays a significant role for normalizing the hormonal imbalance and also improves other disorders like hypertension, anxiety, and depression.[17]

\section{Effect on Skin}

For tightening and firm up the skin a basic Pranayam daily can be helpful. Most importantly, Yoga provides mental peace and emotional balance, both of which are important to radiate beauty from within.[18]

\section{Effect on Cardiovascular System}

Slow type of yogic breathing techniques improves cardiovascular and autonomic variables which might be useful for the prevention and the management of cardiovascular disorders. ${ }^{[19]}$ Through dominance of parasympathetic system, Bhramari pranayama practice improves various cardiovascular parameters in adolescents and it can be practiced routinely for the reduction of stress induced cardiovascular risks in their upcoming period. ${ }^{[20,21]}$ The practice of Bhramari pranayama causes the parasympathetic dominance on cardiovascular system due to its effect in reducing diastolic BP, systolic blood pressure and mean arterial pressure.[22]

Bhramari pranayama (a type of slow breathing) causes significant reduction in the cardiovascular hyper reactivity.[23,24]

Two studies have been done in past by using the cold presser test of which one was on the normal adults while another was done on pregnant women. Those women who were hyper reactive were found to show reduction of blood pressure as a response to the cold pressor test by two months regular practice. [25]

\section{Effect on Respiratory System}

In healthy individuals Bhramari pranayama and $\mathrm{OM}$ chanting are immensely effective in improving the pulmonary function.[26] Deep breathing exercises, even for a few minutes' duration is beneficial for the lung functions. ${ }^{[27]}$ Practice of Bhr.P on a regular basis improves the lung function in healthy adolescents. However further studies on larger number of individuals with a long duration follow-up is required to substantiate the findings.[28]

\section{Effect on EEG waves}

The outcome of Bhramari pranayama on the autonomic nervous system is quiet indispensible. It increases paroxysmal EEG waves soon after practice in healthy volunteers. During the practice of Bhramari pranayama, all the subjects exhibited high frequency hyprerphasic patterns, biphasic waves. They have found strong amplitude gamma waves after 30 days of Bhramari pranayama practice (two sessions per day) and continuous practice would cause the waves to remain for several minutes even after the practice is finished.[29]

\section{Effect on Cognitive Functions}

Enhanced inhibitory response and cognitive control can be noted among the healthy individuals followed by 10 min of Bhr.P practice. Stop signal task can be used as one of the important tool to assess the response inhibition in cognitive psychology, cognitive neuroscience, and psychopathology. Bhramari Pranayama may enhance inhibition response and cognitive control in healthy participants.[30]

\section{Other effects of Bhramari Pranayama}

One study reviled that Bhramari significantly reduced many symptoms associated with tinnitus, such as depression, irritability and anxiety.[31] Bhramari pranayama may serve as a very cost effective and routinely applicable supporting therapy for individuals having tinnitus that probably acts by harmonizing neurological principles.[31] Pranayama seems to have a significant positive effect on test anxiety and test performance. It could be used as an important technique by students prior to their examinations, to reduce their test anxiety and increase their test performance. ${ }^{[32]}$

Humming increases the production of nitric oxide. Humming act as a sonic cleanser and cures the infection of respiratory tract by decreasing the swelling of sinus ostea resulting into better drainage and oxygenation. ${ }^{[3]}$ Humming exercise also increases the vital capacity. It is estimated that humming increases the endogenous generation of nitric oxide level by 15 -fold as compared with the quite exhalation. ${ }^{[34]}$ It has been observed that adding tiny 
amount of nitric oxide to the oxygen to the premature infants prevents blindness, cerebral palsy, and deafness. [35]

Practicing strong humming for one hour on daily basis can put an end to chronic rhino sinusitis in four days by stimulation of endogenous nasal nitric oxide production. It may be helpful in preventing coagulopathies and thus decreasing morbidity due to Covid-19. It leads to enhance immune response, physiological healing and over all wellness.[36]

Bhramari pranayama is efficacious in improving the aerodynamic and acoustic parameters of voice. The results suggests that Bhramari pranayama has an effect on voice related acoustic and aerodynamic parameters by significantly improving the maximum phonation duration for all sustained vowels, glottal airflow and pressure and average fundamental frequency, after practicing Bhramari pranayama. This indicates that the practice of Bhramari pranayama may be helpful in improving the respiratory phonatory coordination and also that with extensive practice one can achieve breathe control.[37]

Bhramari Pranayama and Yoga Nidra if practiced together can significantly alleviate the stress induced changes in cardio-respiratory parameters. Yoga is undoubtedly a trouble-free and cost effective way for reducing damaging effects of stress and if incorporated in our lifestyle yoga can honour us with a long, healthy and disease-free life.[38]

Integrating regular practicing of Bhramari pranayama along with the conventional management of chronic rhinosinusitis is more efficacious than conventional management alone. [39]

Research suggests that long Pranayamic breathing chanting activates the parasympathetic system and by lowering our stress level will definitely increase our confidence level.[40]

Bhramari Pranayam, releases nitric oxide and when combined with Kumbhak, Greeva Chalan along with modifying diet and lifestyle can prevent or delay the aging hearing loss. It potentiates immunity and senile degeneration (dementia Alzheimer's) including old age deafness. ${ }^{[41]}$

\section{DISCUSSION}

There are few influencing scientific bases regarding constant physiological changes produced when Pranayama is practiced. Still, there subsists a dearth of literature of clinical efficacy of Bhramari pranayama on physiological systems. Pranayama is one practice that has been found to be effective to physiology of mankind in many ways.

Prānāyāma is one among the important divisions of the ancient traditional Yoga practices. Different types of Prānāyāma techniques were shown to produce different effects, in which there is lack of consistency in the results of specific nostril yogic breathing and the mechanisms behind the effects of various Prānāyāma. Hence, more future studies have to be put forth in the field of Prānāyāma to explore its precise effect with the underlying mechanisms. Pranyamas such as Savitri, Kapalabhati, Bhasrika, Nadisuddhi and Bhramari cause pronounced physiological responses.

Though various studies have been already done in the past but there is some new concept which is being tried to be added with this article for the purpose of further studies. Very few studies focusing on post menopausal symptoms have been done. In post menopausal women, irritability, mood swings, insomnia, difficulty in concentrating, mental confusion, stress incontinence, depression, headache and vasomotor symptoms occurs. Bhramari pranayam would surely be very helpful to combat these conditions and will also be very helpful to prevent women from risk of many upcoming ailments in their future life. Bhramari generates vibrations in our brain and causes relief in these symptoms by various mechanisms.

Cortisol that is considered as a major stress hormone causes increased oil production from skin glands, which can finally lead to clogged pores which causes acne breakouts. Prolonged stress leads to sustained increased levels of these hormones and can produce negative effect on your skin health. Practicing Bhramari pranayama causes reduction of cortisol level which will effect on stress level and finally it may induce happiness and will surely increase dopamine which will reflect on skin physiology, as it has been told by Acharya charaka in Indriya upakramniya Adhyaya "Twaka cheta samavayi" seems to be very relatable here. Through which glow in the skin or health of the skin can be increased.

Stress plays a significant role in provoking cardiac arrhythmia by exerting overpowering effects on electrophysiology of the cells of myocardiam and the cardiac rhythm. Psychological and physiological stressors influence the cardiovascular system through the autonomic nervous system. There are many studies suggesting reduction of stress by practicing Bhramari pranayam. Further studies can be done to check the effect of Bhramari on patients having Cardiac arrhythmias.

Due to fear of spreading of Covid 19 infection and lockdown restrictions, large no. of family members are residing in their home resulting in stress related conditions in most of them. Bhramari pranayama is very efficient in lowering stress level and should be practiced by everyone in today's scenario. As Bhramari can be practiced by every age group without requiring any specific conditions to be practiced and its cost effectiveness, it can be practiced to prevent upcoming consequences of Covid 19 pandemic. 
Bhramari pranayam produces acoustic vibration that could have significant impact in producing the desired effect. Since, for other parts of the body we do have stretching exercises, Yoga asanas and many other forms but for brain we don't have such practices. In this context Bhramari pranayam is good alternative and a unique technique which produces vibration of head and vibration by one's own voice might not be harmful for the brain tissues.

\section{CONCLUSION}

From such multiple evidences it can be conclude that Bhramari influences multiple systems in the body and it is definitely very relevant in current grievous Covid 19 pandemic as Bhramari lowers the stress, produce calmness and enhance tranquility in several ways. There is definitely having scope to have desirable effects on respiratory system, autonomic nervous system, stress, anxiety level and over all emotional status of the practitioner. However there arises a need for focusing on strengthening the methodology and study designs for more reliable and valid result. Due to its high degree of reproducibility, RCTs are accepted universally as a top rated study design. Therefore more RCTs are required in this field to fulfill the dearth literature on the effect of Bhramari Pranayam empirically.

\section{REFERENCES}

1. Mooventhan A., \& Khode, V Effect of Bhramari pranayama and OM chanting on pulmonary function in healthy individuals: A prospective randomized control trial. International journal of yoga, 2014; 7(2), 104-110.

2. Veerabhadrappa S.G., Herur A., Patil S. Effect of yogic bellows on cardiovascular autonomic reactivity. J Cardiovasc Dis Res. 2011; 2(4): 223227.

3. Chodzinski J. The effect of rhythmic breathing on blood pressure in hypertensive adults. J Undergrad Res. 2000; 1(6): 78-98.

4. Bijlani R. The yogic practices: asanas, pranayamas and kriyas. Underst Med Physiol. 2004; 3:883-885

5. Aasana pranayama mudra bandha by swami satyananda saraswati eighth reprint 1995 published by swami satyananda honorary secretary bihar school of yoga. P.296.

6. K.R. Srikanta Murthy; Sarngadhara samhita A treatise on Ayurveda; ch.5 shloka 49, sixth edition 2006 Chaukhamba Orientalia, page25.

7. Aasana pranayama mudra bandha by swami satyananda saraswati eighth reprint 1995 published by swami satyananda honorary secretary bihar school of yoga P.301.

8. Aasana pranayama mudra bandha by swami satyananda saraswati eighth reprint 1995 published by swami satyananda honorary secretary Bihar school of yoga P.299.

9. Aasana pranayama mudra bandha by swami satyananda saraswati eighth reprint 1995 published by swami satyananda honorary secretary bihar school of yoga P.300.

10. Light on Pranayama, Pranayama Dipika by B.k.S Iyengar London Unwin Paperbacks First published by Unwin Paperbacks 1983 Reprinted 1983 page 152

11. Swami Niranjanananda Saraswati; Gheranda Samhita Commentary on the yoga teachings of Maharshi Gheranda; Yoga Publication Trust, first published 2012

12. Kuppusamy M, Kamaldeen D, Pitani R, Amaldas J, Shanmugam PJ, Effects of Bhramari Pranayama on health - A systematic review. Tradit Complement Med. 2018 Jan; 8(1):11-16

13. Saraswati SS. Asana Pranayama Mudra Bandha. Reprint Edition. Munger, Bihar: Yoga Publication Trust; 2009.

14. Jerath R., Edry J.W., Barnes V.A., Jerath V. Physiology of long pranayamic breathing: neural respiratory elements may provide a mechanism that explains how slow deep breathing shifts the autonomic nervous system. Med Hypotheses. 2006; 67(3): 566-571.

15. Pranayama N., Pranayama B.V., Pranayama B.M. Heart rate alterations in different types of pranayamas. Indian J I'nysiol Phannacol. 1992; 36(4): 20-288

16. Light on Pranayama, Pranayama Dipika by B.k.S Iyengar London UNWIN PAPERBACKS First published by Unwin Paperbacks 1983 Reprinted 1983 page 152.

17. Nespor K. Yoga in addictive diseases-practical experience. Alcologia Bologna. 2001; 13(1): 21-25

18. Swati chaturvedi, In pursuit of that smooth, healthy, skin; Hindustan times 19 June 2021 page 07.

19. Nivethitha, L., Mooventhan, A., \& Manjunath, N. K. Effects of Various Prānāyāma on Cardiovascular and Autonomic Variables. Ancient science of life, 2016; 36(2), 72-77.

20. Kuppusamy, M., Kamaldeen, D., Pitani, R., \& Amaldas, J. Immediate Effects of Bhramari Pranayama on Resting Cardiovascular Parameters in Healthy Adolescents. Journal of clinical and diagnostic research: JCDR, 2016; 10(5), CC17CC19.

21. Samiksha Sathe, Kirti Thodge, Tejal Rajandekar, Anshu Agrawal; To find out immediate effect of Bhramari Pranayama on Blood Pressure, Heart Rate and Oxygen Saturation in Hypertensive Patients; International Journal of Current Research 
and Review. Vol 12 Issue 19, October, 2020, Pages: 193-197

22. Pramanik, T., Pudasaini, B., \& Prajapati, R. Immediate effect of a slow pace breathing exercise Bhramari pranayama on blood pressure and heart rate. Nepal Medical College journal: NMCJ, 2010; 12(3), 154-157.

23. Jain G, Rajak C, Rampalliwar S, Effect of Bhramari Pranayama on Volunteers Having Cardiovascular Hyper-reactivity to Cold Pressor Test. J Yoga Phys Therapy; 2011; 1:102.

24. Rampalliwar S, Rajak C, Arjariya R, Poonia M, Bajpai R. The effect of Bhramari pranayama on pregnant women having cardiovascular hyper reactivity to cold pressor. Natl J Physiol Pharm Pharmacol 2013; 3:137-141.

25. Rampalliwar S., Rajak C., Arjariya R., Poonia M., Bajpai R. The effect of Bhramari Pranayama on pregnant women having cardiovascular hyperreactivity to cold pressor. Natl J Physiol Pharm Pharmacol. 2013; 3: 128-133.

26. Mooventhan, A., \& Khode, V. Effect of Bhramari pranayama and $\mathrm{OM}$ chanting on pulmonary function in healthy individuals: A prospective randomized control trial. International journal of yoga, 2014; 7(2), 104-110.

27. Sivakumar, G., Prabhu, K., Baliga, R., Pai, M. K., \& Manjunatha, S. Acute effects of deep breathing for a short duration (2-10 minutes) on pulmonary functions in healthy young volunteers. Indian journal of physiology and pharmacology, 2011; 55(2), 154-159.

28. Kuppusamy, M., Dilara, K., Ravishankar, P., \& Julius, A. Effect of Bhrāmarī Prānāyāma Practice on Pulmonary Function in Healthy Adolescents: A Randomized Control Study. Ancient science of life, 2017; 36(4), 196-199.

29. Vialatte F.B., Bakardjian H., Prasad R., Cichocki A. EEG paroxysmal gamma waves during Bhramari Pranayama: a yoga breathing technique. Conscious Cognit. 2009; 18(4): 977-988.

30. Rajesh, S. K., Ilavarasu, J. V., \& Srinivasan, T. M. Effect of Bhramari Pranayama on response inhibition: Evidence from the stop signal task. International journal of yoga, 2014;7(2), 138-141.

\section{Cite this article as:}

Nisha Garg, Srikanta Kumar Panda. Bhramari Pranayama: A Non-Pharmacological Approach Against Current Coronavirus Disease-19 Pandemic. International Journal of Ayurveda and Pharma Research. 2021;9(8):97-102.

https://doi.org/10.47070/ijapr.v9i8.1970

Source of support: Nil, Conflict of interest: None Declared
31. Pandey S., Mahato N.K., Navale R. Role of selfinduced sound therapy: bhramari pranayama in tinnitus. Audiol Med. 2010; 8(3):137-141.

32. Nemati A. The effect of pranayama on test anxiety and test performance. International journal of yoga, 2013; 6(1), 55-60.

33. Eby GA. Strong humming for one hour daily to terminate chronic rhino sinusitis in four days: A case report and hypothesis for action by stimulation of endogenous nasal nitric oxide production. Med Hypotheses 2006; 66: 851-4

34. Maniscalo M. Humming, nitric oxide and paranasal sinuses ventilation. Eur Respir J 2003; 22: 323-9

35. Eastor J. Inhaled Nitric Oxide Protects the Brains of High Risk Premature Infants, Press Release, University of Chicago; 2006. Available from: http://www.uchohospitals.edu/news/20050 707-oxide.html.

36. Taneja M. K. Modified Bhramari Pranayama in Covid 19 Infection. Indian journal of otolaryngology and head and neck surgery: official publication of the Association of Otolaryngologists of India, 2020; 72(3), 395-397.

37. Manjunatha, U., Bhat, J. S., Radish, K. B., Bajaj, G., Shruthi, P., Suresh Nayak, P., \& Rasheeka, S. M. Effect of Bhramari Pranayama on the Acoustic and Aerodynamic Parameters of Voice in Normophonic Females. Evidence-based complementary and alternative medicine: eCAM, 2018, 4176803.

38. Bajpai R, Rajak C, Rampalliwar S. Effect of Bhramari Pranayama and Yoga Nidra on cardiovascular hyper-reactivity to cold pressor test. Inter J Medical Sci Res Prac 2015;2(1):24-26.

39. Abishek, K., Bakshi, S. S., \& Bhavanani, A. B. The Efficacy of Yogic Breathing Exercise Bhramari Pranayama in Relieving Symptoms of Chronic Rhinosinusitis. International journal of yoga, 2019; 12(2), 120-123.

40. Dr. Megha Rastogi \& Mr. Kamal Kishore, A Study of the effect of Surya Namskar and Bhramari Pranayam on Self Confidence International Journal of Yoga and Allied Sciences, Volume: 4, Issue: 1; Jan- June 2015

41. Taneja M K. Nitric oxide Bhramari Pranayam and deafness. Indian J Otol 2016; 22:1-3.

Disclaimer: IJAPR is solely owned by Mahadev Publications - dedicated to publish quality research, while every effort has been taken to verify the accuracy of the content published in our Journal. IJAPR cannot accept any responsibility or liability for the articles content which are published. The views expressed in articles by our contributing authors are not necessarily those of IJAPR editor or editorial board members. 